\title{
Cikkismertetés: A társadalmi-gazdasági egyenlőtlenségek hatása az egészségtelen életmódot mérő kiterjesztett eszköz és az egészségi állapot közötti kölcsönhatásra
}

\author{
Article review: The effect of socioeconomic deprivation on the association \\ between an extended measurement of unhealthy lifestyle factors and \\ health outcomes
}

\author{
Ismertető: $\quad$ Csizmadia Péter $\square$ \\ Nemzeti Népegészségügyi Központ
}
Ismertetett cikk: Foster HME, Celis-Morales CA, Nicholl Bi et al. The effect of socioeconomic deprivation on the association between an extended measurement of unhealthy lifestyle factors and health outcomes: a prospective analysis of the UK Biobank cohort. Lancet Public Health 2018;3(12): e576-85. doi: 10.1016/S2468-2667(18)30200-7

Beküldve: $\quad$ 2019. 02. 01.

doi: $\quad$ 10.24365/ef.v60i1.419

Kulcsszavak: egészségegyenlőtlenségek

Keywords: health inequalities

\section{HÁTTÉR}

Az életmódbeli tényezők egymással kölcsönhatásba lépve növelik a halandóságot. A dohányzás és az alkoholfogyasztás esetében ezek az egymást felerősítő hatások jól ismertek, de az újabb vizsgált tényezők esetében, mint például a televíziózással eltöltött idő, nem rendelkezünk pontos tudással. Továbbra is tisztázatlan a társadalmi-gazdasági depriváció, vagyis a hátrányos helyzet életmódra gyakorolt negatív hatása. Az itt ismertetett kutatás célja annak vizsgálata, hogy a depriváció módosítjae az életmódbeli kockázati tényezők pontszáma és az egészségi állapot közötti összefüggéseket.

\section{MÓDSZEREK}

A prospektív elemzés adatai az Egyesült Királyság Biobankjából származtak, egy követéses vizsgálatból. Minden résztvevő egy kiterjesztett életmód kockázati pontszámot kapott. Egy pont járt az egészségtelen életmód minden tényezőjéért (a dohányzás, a túlzott alkoholfogyasztás, az egészségtelen étrend mellett az alvási időtartamot és a hosszas televíziónézéssel töltött időt is beleértve, az olajos halak vagy gyümölcsök és zöldségek ritka, valamint a nagy mennyiségú vörös vagy feldolgozott hús fogyasztása és az alacsony fizikai aktivitás). A leginkább egészséges (0-2 pont), mérsékelten egészséges (pontszám 3-5), vagy legkevésbé egészséges (6-9 pont) kategóriákat hozták létre.

Cox-féle arányos kockázati regressziós modellt alkalmaztak az életmód pontszám és az egészségi állapot közötti összefüggés vizsgálatára (kimenet az összes halálozás, valamint a szív- és érrendszeri betegségek mortalitása és előfordulása volt), és hogy ez az összefüggés módosult-e a depriváció által. A deprivációs indexet a népszámlálási adatok alapján hozták létre az autótulajdon, a háztartás túlzsúfoltsága, a foglalkozás, a foglalkoztatottság és a lakóhely figyelembe vételével. Az elemzésből kizárták azokat, akik a követéses vizsgálatba történő felvételt követő két évben elhaláloztak, vagy szív- 
és érrendszeri betegségük alakult ki. Szintén kizárásra kerültek a nem fertőző betegségekben (kivéve magas vérnyomás) szenvedő és hiányzó kovariancia adatokkal rendelkező alanyok. A vizsgálatból ugyancsak kizárásra kerültek azok a résztvevők, akiknek a fizikai aktivitásáról, az alvási időtartamáról és a teljes képernyő előtt eltöltött idejéről nem állt rendelkezésre megbízható adat. Minden elemzést korrigáltak kor, nem, etnikai hovatartozás, felmérés hónapja, magasvérnyomás-betegség története, szisztolés vérnyomás, magas koleszterinszint vagy magas vérnyomás gyógyszerek használata esetén, valamint testtömeg-index kategóriák alapján.

\section{EREDMÉNYEK}

A vizsgálatba 328 594, 40-69 éves korú egyént vontak be többéves után követéssel. A legkevésbé deprivált ötödben a korrigált kockázati arány a legkevésbé egészséges életmód kategóriában a legegészségesebb életmód kategóriához képest 1,65 volt az összes halálozás esetében, 1,93 a szívés érrendszeri megbetegedések mortalitása esetében, és 1,29 a szív- és érrendszeri megbetegedések előfordulására. Ugyanezek a kockázati arányok a leginkább deprivált ötödben 2,47, 3,36 és 1,41 voltak. Továbbá a szív- és érrendszeri megbetegedések mortalitása esetében közel kétszeresére nő a kockázati arány a legdepriváltabb csoportján belül a viszonylag jó életmód pontszámot kapók és legkevésbé egészséges életmódot folytatók között Jelentős kölcsönhatást mutattak ki az életmód és a depriváció között az összes, valamint a szívés érrendszeri betegségek okozta halálozás esetében, de a szív- és érrendszeri megbetegedések előfordulása esetén nem.

\section{KÖVETKEZTETÉSEK}

Az életmóddal összefüggő kockázati tényezők kölcsönhatásai a hátrányos helyzetű népesség esetében aránytalan károkat okoznak. A népegészségügyi és az egyéneket célzó beavatkozások mellett olyan, a szegénység csökkentésére irányuló szociális és költségvetési politikára van szükség, amely az életmódbeli tényezők szélesebb körét képes pozitív irányba befolyásolni.

\section{TANULSÁGOK A HAZAI SZAKEMBEREK SZÁMÁRA}

A tanulmány szerint a rossz társadalmi-gazdasági helyzetben lévők esetében nagyobb az életmód szerepe, mint a jobb társadalmi-gazdasági helyzetűek esetében. Ebből következik, hogy ennél a rétegnél fontosabb előmozdítani az életmódváltást, hatékonyabb az erőforrásokat odakoncentrálni, valamint célzott prevenció és komplex életmód programokat kidolgozni, megvalósítani. A népegészségügyi eszközök mellett a szociális és pénzügyi kormányzat részéről is szükségesek azon intézkedések, amelyek megszüntetik a társadalmigazdasági javakhoz való egyenlőtlen hozzáférést. 